American Journal of Infectious Diseases 7 (2): 32-39, 2011

ISSN 1553-6203

(C) 2011 Science Publications

\title{
Impact of Human Immune Deficiency Virus and Acquired Immune Deficiency Syndrome on Farm Households
}

\author{
${ }^{1}$ Okezie Chukwukere Austin, ${ }^{2}$ Athenesius Onyekanma \\ and ${ }^{1}$ Amir Hussin Baharuddin \\ ${ }^{1}$ Department of Postgraduate Studies and Research, School of Social Sciences, \\ University Sains Malaysia, Penang Malaysia \\ ${ }^{2}$ Department of Agricultural Economics, College of Agricultural Economics, \\ Rural Sociology and Extension, \\ Michael Okpara University of Agriculture, Umudike Nigeria
}

\begin{abstract}
Problem statement: The impact of HIV/AIDS in Africa cut across all sectors of human development and it poses serious challenge to the survival of several vulnerable poor, whose livelihood depends solely on agriculture. This study is an attempt to contribute to the understanding of HIV/AIDS by investigating household vulnerablity and its impact on production variability in farm households. Approach: A total of 110 households were involved inthe study split into households with and without infection. Data analysis involved the use of descriptive statistics and the estimation of the stochastic frontier model. Results: The vulnerability factors showed that $10.12 \%$ of the households were vulnerable to HIV. The important indices of vulnerability include non-use of condoms and having multiple sex partners. Farm size, labour and education were significant and positive determinants of productivity variability in both households. Access to credit had a positive effect on productivity in households with infection and impacted negatively on households without infection. Conclusion: Households with infection were grossly inefficient compared to households without infection. The mean economic efficiency in households with infection is $49 \%$ against $79 \%$ in households without infection. The policy outcome of the study is to equip Primary Health Centre's (PHC) and re-structural extension services to be more goal-driven.
\end{abstract}

Key words: HIV/AIDS, Primary Health Centre's (PHC), Millennium Development Goals (MDGs), human immune, farm households, vulnerability factors, productivity variability, pandemic stage, infections occurred

\section{INTRODUCTION}

The emergence of HIV/AIDS is one of the most devastating occurrences in human history. The Human Immune Deficiency Virus (HIV) puts the entire body's natural defensive mechanism out of action so that other viruses or bacteria can attack the body systems leading to full-blown pandemic stage referred to as Acquired Immune Deficiency Syndrome (AIDS). The general consensus now is that AIDS is a profound human tragedy, which has gone beyond a mere health problem, but a real threat to economic growth and development (Robert et al., 2006; Kermyt and Beutel, 2007; Pradeep et al., 2010). A major and challenging aspect of the Millennium Development Goals (MDGs) is halting and reversing the trend of HIV/AIDS infection by 2015.
Sub-Saharan Africa (SSA)-where an estimated 26.6 million people are living with HIV and approximately 3.2 million new infections occurred in 2003 is the region of the world that is most affected by AIDS (CTA, 2004; Sarder et al., 2006; Jamshidi et al., 2010). The number of people living with HIV/AIDS has continued to rise from 36.2 million in 2003 to 38.6 million in 2005. Specifically, 4.1 million new infections occurred in 2005, while the number of HIV/AIDSrelated deaths increased to 2.8 million. Sub-Saharan Africa (SSA), where $64 \%$ of HIV-positive people in the world live, bears the greatest burden of HIV/AIDS (Joseph, 2005; United Nations, 2006). In Nigeria, however, HIV prevalence rate is lower than in some other African countries, but the absolute number of people affected may be larger in some cases. The 1991 sentinel survey showed that Nigeria with a population

Corresponding Author: Okezie Chukwukere Austin, Department of Postgraduate Studies and Research School of Social Sciences, University Sains Malaysia, Penang Malaysia 
of over 120 million is having national sero prevalence of $1.8 \%$ and this increased to $3.8 \%$ in $1994,4.5 \%$ in 1995 and $5.4 \%$ in 1999 , representing a $20 \%$ increase in overall HIV prevalence rates (UNAIDS, 2001; 2002).

The impact of HIV/AIDS in Africa cuts across all sectors of human development and it poses serious challenge to the survival of several vulnerable poor whose livelihood depends solely on agriculture. Given the recent emergence of health challenges such as HIV/AIDS, malaria, tuberculosis and several other Sexually Transmitted Diseases (STDs), which are not only massive killers, but systematic wasters, the linkage between agriculture and health sector must be addressed for some significant policy interventions (Nirmala et al., 2009; Sumathi et al., 2010). HIV/AIDS is a major threat to agriculture and food security, not because attacked crops or livestock, but because it reduces agricultural productivity and diminishes the availability of food through direct loss of family labour, reduction in time allocated to family, sales of farm assets, cultivation of marginal land and marginalization of surviving widow from land ownership by customary land tenure system (Ambe-Uva, 2005).

Very little of research has been about the actual sectoral and industrial impact of HIV as opposed to its probable impact, given the structural characteristics of production. Much applied study needs to be done to fill in the huge gaps in understanding and to identify the scale and scope for policy response. This microlevel study is an attempt to quantify the impact of HIV/AIDS on the productivity of farm households by estimating and computing economic efficiency indices. The study is guided by the hypotheses that farm households irrespective of their HIV/AIDS status experience production variability and are therefore efficient. Again socio-economic and demographic characteristics do not have influence on farm productivity.

\section{MATERIALS AND METHODS}

The study area: Abia State is located in the south-east geopolitical area of Nigeria. The state falls within the tropical Rainforest Belt of Nigeria. The Belt is characterized by high rainfall and low temperature during the rainy season, which often lasts for about 7 months (April to October). The dry season period is characterized by high temperature and very erratic and low rainfall and it lasts for about 5 months (November to March). The vegetation cover ranges from deciduous and hard wood where the forest is preserved to shrubs and grasses where the land had been used for agricultural production.
The population of the state was estimated at $2,881,380$ in 2006 (NPC, 2006). The population density is about 364 person $\mathrm{km}^{-2}$ with $63 \%$ in agricultural production. Abia State comprises of 17 Local Government Areas (LGAs) divided into three agricultural zones, namely, Aba, Ohafia and Umuahia. In Aba zone there are seven LGAs namely: Aba North, Aba South, Osisioma Ngwa, Obi Ngwa, Ukwa East, Ukwa West and Ugwunagbo, In Ohafia zone, there are five LGAs namely: Isiukwuato, Ohafia, Bende, Arochukwu and Umunneochi. In Umuahia zone, there are five LGAs namely: Umuahia North, Umuahia South, Ikwuano, Isiala Ngwa North and Isiala Ngwa South.

Sampling: The study adopted a purposive multi-stage sampling procedure. The first stage involved the purposive selection of Abia State based on the relevance of agricultural production and prevalence rate of HIV/AIDS infection. At the second stage, two Local Government Areas (LGAs) from each zone was selected where HIV/AIDS problem are prevalent based on preliminary information from State Ministry of Health (MOH) and Agricultural Development Project (ADP). The extension officers working in selected villages assisted in identifying households with patients suffering from the disease. Once an infected household is selected, a household within the immediate proximity is identified and selected with on record of infection. A total of 140 households were enlisted in the study but after sieving a total of 110 were found useful for the study. The data spread involved 65 households with infection and 45 households without infection.

Data collection techniques: Primary data were collected in the study. A structured questionnaire was used to collect data pertaining to the dermography, socio economic variables and the manifestations of the pandemic disease. The range of data covered agricultural activities, use of farm resources, time allocation, expenditure on medicare and labour use in households.

Data analysis: Descriptive and econometric methods were used to determine the impacts of HIV/AIDS on agricultural productivity. Descriptive tools used are frequencies and percentages. According to Christiaensen and Subbarao (2005), vulnerability of households to HIV/AIDS is their capacity to cope with, resist and recover from HIV/AIDS infection, while Oyekale (2004) regards vulnerability as a function of exposure to risk and inability to cope. The fussy set approach has been used to analyse the data. Following is the application of the fussy set approach as adopted in Luers et al. (2003) and Masuku and Sittole (2009). 
One can state that for the population $\mathrm{N}$ made up of n households i.e., $(\mathrm{N}=\{\mathrm{hh} 1, \mathrm{hh} 2, \mathrm{hh} 3 \ldots \mathrm{hhn}\}, \mathrm{V}$ is a subset of $\mathrm{v}$ households that have some degree of vulnerability to HIV/AIDS-hence impacted by the pandemic. Thus $\mathrm{v} \leq \mathrm{n}$ and $\mathrm{v}=0$ implies that there are no vulnerable households and $\mathrm{v}=\mathrm{n}$ implies that all households are vulnerable.

One can also break down the vulnerability $\mathrm{X}$ into $\mathrm{m}$ specific dimensions of impact and give a corresponding weight (wi, $\mathrm{i}=1, \ldots, \mathrm{m}$ ) to each dimension. The weights can be predetermined, or developed using an appropriate function.

The vulnerability of any given household hhi $\mathrm{I}=$ $1 \ldots \mathrm{n}$ to the $\mathrm{jth} \mathrm{j}=1, \ldots \mathrm{m}$ dimension of impact can be expressed as $\mathrm{Xij}$ and set to take values between 0 and 1 such that $0=$ no impact and 1 full impact. Thus each $\mathrm{Xij}$ denotes the degree of vulnerability of household $\mathrm{i}$ to the jth dimension of impact and Xijwi will be the corresponding weighted vulnerability.

The sum of the weighted vulnerabilities across all dimensions give the particular household's total vulnerability Vhhi to HIV/AIDS, that is Eq. 1:

$\sum_{j=1}^{m} X w j / \sum_{j=1}^{m} W j=$ Vhhi

It is also possible to sum down the dimensions and calculate the particular dimension's contribution to vulnerability to HIV/AIDS.

For the study, the sum of the weights has been conveniently set to Eq. 2:

$\sum_{j=1}^{m} \mathrm{Wj}=100$

The household vulnerability index was calculated as follows:

- Selecting appropriate dimensions of impact

- Selecting variables from collected data to describe these dimensions

- Setting the goal posts for each variable: maximum and minimum values

- Developing a matrix of weights for the dimensions. Each variable is given an appropriate weight within its cluster using the predetermined weights. The sum of weights is divided by 100 to ensure that the weighting remains between 0 and 1

Next we calculate the individual variable indices as a number between 0 and 100 by using Eq. 3:

$\frac{\text { actual value }- \text { minimium value }}{\text { maximium value }- \text { minimium value }}$ X100
- The Household Vulnerability Index (HVI) is then computed for the total mark using the formula: Household Vulnerability Index $(\mathrm{HVI})=$ average value of individual indices.

Efficiency model: The efficiency model was adopted to ascertain the impact of HIV/AIDS on agricultural productivity. The stochastic frontier 4.1 model by Coelli (1996) is one of the available and most widely used stochastic packages for efficiency analysis. This package was used to estimate the maximum likelihood estimates and coefficients of the socio-economic determinants of inefficiency arising from HIV/AIDS infection in households Eq. 4:

$\log \mathrm{Yi}=\beta \mathrm{o}+\beta_{1} \log \mathrm{X}_{1} \mathrm{i}+\beta_{2} \log \mathrm{X}_{2} \mathrm{i}+$

$\beta_{3} \log \mathrm{X}_{3} \mathrm{i}+\beta_{4} \mathrm{X}_{4} \mathrm{i}+\beta_{5} \mathrm{X}_{5} \mathrm{i}+(\mathrm{Vi}-\mathrm{Ui})$

Where:

Log $=$ Natural Logarithm

$\mathrm{Yi}=$ Agricultural productivity defined as the total value of crop production divided by the cost of production

$\mathrm{X}_{1 \mathrm{i}}=$ Farm size (hectares)

$\mathrm{X}_{2 \mathrm{i}}=$ Cost of family labour (Naira)

$\mathrm{X}_{3 \mathrm{i}}=$ Cost if hired labour (Naira)

$\mathrm{X}_{4 \mathrm{i}}=$ Cost of seed (Naira)

$\mathrm{X}_{5 \mathrm{i}}=$ Cost of fertilizer (Naira)

$\mathrm{Vi}=$ Symmetry error

$\beta \mathrm{i}$ 's $=$ Unknown parameters to be estimated

$\mathrm{Vi}=$ Represents independently and identically distributed random errors $\mathrm{N}\left(0, \sigma_{\mathrm{v}}{ }^{2}\right)$

$\mathrm{Ui}=$ Represents non-negative random variables which are independently andidentically distributed as $\mathrm{N}\left(0, \sigma_{\mathrm{v}}{ }^{2}\right)$ i.e., the distribution of $\mathrm{Ui}$ is half normal. $|\mathrm{Ui}|>0$ reflects the technical efficiency relative to the frontier production function. $|\mathrm{Ui}|=0$ for a farm whose production lies on the frontier and $|\mathrm{Ui}|>0$ for a farm whose production lies below the frontier

The inefficiency model can be stated as follows Eq. 5:

$\mathrm{U}_{\mathrm{i}}=\delta_{0}+\delta_{1} \mathrm{Age}+\delta_{2} \mathrm{Fex}+\delta_{3} \mathrm{Edu}+\delta_{4} \mathrm{Dis}+\delta_{5} \mathrm{Sic}+\delta_{6}$

$\mathrm{Fer}+\delta_{7} \mathrm{Cop}+\delta_{8} \mathrm{Acc}+\delta_{9} \mathrm{Ext}+\delta_{10} \mathrm{Hss}+\mathrm{Wi}$.

Where:

$\mathrm{Ui}=$ Inefficiency of ith farmer

Age $=$ Sex of house head, $\mathrm{M}=1$, Otherwise 0

Fex $=$ Farming experience in years

$\mathrm{Edu}=$ Total side days in a season

Dis $=$ Distance from market $(\mathrm{km})$

Sic $=$ Total market days lost due to sickness 
Fer = Quantity of fertilizer used in season (Naira)

Cop $=$ Memberships of cooperative society Yes $=1$, otherwise $=0$

Acc $=$ Access to credit, Yes $=1$, otherwise 0

Ext $=$ Extension visit, Yes $=1$, otherwise 0

Hss $=$ Household size

$\mathrm{Wi}=$ An error term that follows a truncated normal distribution and

$\delta \mathrm{i}$ 's $=$ Inefficiency parameters to be estimated

The Cobb-Douglas production frontier function defined by Eq. 3 and the inefficiency model defined by Eq. 4 are jointly estimated by the MaximumLikelihood (ML) method using FRONTIER 4.1 (Coelli 1996).

\section{RESULTS}

HIV/AIDS Vulnerability. Vulnerability measures the extent to which an individual household member is exposed to the risk of exposure to HIV/AIDS. The vulnerability factors range from socio-economic factors and behavioural attributes. Vulnerability indicators following previous studies by Oyekale (2004) were adopted in assessing the risk on household members. The results are presented in Table 1 .

Hypothesis testing and model robustness: Before proceeding to examine the parameter estimates of the production frontier and the factors that affect the efficiency of farm households with or without HIV/AIDS infection, we investigate the validity of the model used for the analysis. These various tests of null hypotheses for the parameters in the frontier production function and in the inefficiency models are performed using the generalized likelihood-ratio test statistic defined by: $\gamma=-2\left\{\log \left[\mathrm{L}\left(\mathrm{H}_{0}\right)-\log \left[\mathrm{L}\left(\mathrm{H}_{1}\right)\right]\right\}\right.$, where $\mathrm{L}$
$\left(\mathrm{H}_{0}\right)$ and $\mathrm{L}\left(\mathrm{H}_{1}\right)$ denote the values of the likelihood function under the null $\left(\mathrm{H}_{0}\right)$ and alternative $\left(\mathrm{H}_{1}\right)$ hypotheses, respectively. If the null hypothesis is true, the LR test statistic has an approximately a chi-square or a mixed chi-square distribution with degrees of freedom equal to the difference between the number of parameters in the unrestricted and restricted models.

First we tested the null hypothesis $\mathrm{H}_{0}: \gamma=\delta_{0}=\delta_{1}$ $=\ldots=\delta_{10}=0$, which specifies that the technical inefficiency effects are not present in the model regardless of HIV/AIDS status. The hypothesis is rejected as gamma parameter (Table 2) is 0.93 and significant at $1 \%$ probability level, which means about $93 \%$ of the disturbance term is due to inefficiency for households with HIV/AIDS. In households without HIV/AIDS, $85 \%$ of the disturbance term is as a result of inefficiency and is also significant at $1 \%$. Thus the inclusion of the technical inefficiency term is a significant addition to our model.

The second null hypothesis which is tested is $\mathrm{H} 0$ : $\delta_{1}=\ldots=\delta_{10}=0$ implying that the farm-level technical inefficiencies are not affected by the farm- /farmeroriented variables, policy variables and/or socioeconomic variables included in the inefficiency model. This hypothesis is also rejected, implying the variables present in the inefficiency model have collectively significant contribution in explaining technical inefficiency effects for the maize farmers.

The results of a likelihood ratio test $(\mathrm{LR}=19.81$ and 39.31) for households with and without HIV/AIDS infection respectively confirms that productivity variability's predominantly relate to the variance in farm management (efficient use of available resource). Efficiency in this study is seen in terms of agricultural productivity in households. The results of the likelihood estimates of productivity in households with and without HIV/AIDS infection is presented in Table 2.

Table 1: Percentage contributions of HIV/AIDS vulnerability indicators

\begin{tabular}{|c|c|c|c|c|c|c|c|}
\hline Indicators & Ukwa East & Ukwa West & Umuahia North & Isiala Ngwa North & Ohafia & Arochukwu & Total \\
\hline Don't believe AIDS exist & 0.56 & 0.86 & 0.22 & 0.61 & 0.58 & 0.75 & 0.610 \\
\hline Have more than one sex partner & 0.60 & 0.96 & 0.98 & 0.59 & 0.53 & 0.53 & 0.730 \\
\hline Do not use condom & 0.73 & 0.94 & 0.29 & 0.81 & 0.49 & 0.58 & 0.810 \\
\hline Cannot get condom & 0.90 & 0.51 & 0.73 & 0.83 & 0.61 & 0.67 & 0.610 \\
\hline Share injection needles & 0.43 & 0.91 & 0.81 & 0.95 & 0.63 & 0.78 & 0.730 \\
\hline No new syringe & 0.70 & 0.88 & 0.61 & 0.77 & 0.21 & 0.77 & 0.430 \\
\hline Touch unscreened blood & 0.81 & 0.31 & 0.63 & 0.69 & 0.29 & 0.61 & 0.510 \\
\hline Share Clippers & 0.21 & 0.29 & 0.63 & 0.81 & 0.30 & 0.63 & 0.520 \\
\hline Visit prostitutes & 0.59 & 0.77 & 0.91 & 0.68 & 0.39 & 0.81 & 0.630 \\
\hline Care not to touch blood & 0.58 & 0.82 & 0.81 & 0.77 & 0.61 & 0.89 & 0.710 \\
\hline Do not care to contract AIDS & 0.83 & 0.81 & 0.66 & 0.61 & 0.65 & 0.22 & 0.810 \\
\hline Don't know preventive methods & 0.51 & 0.82 & 0.71 & 0.51 & 0.66 & 0.29 & 0.490 \\
\hline Have not heard about AIDS & 0.92 & 0.33 & 0.69 & 0.58 & 0.81 & 0.39 & 0.590 \\
\hline Wife/Husband HIV positive & 0.77 & 0.17 & 0.69 & 0.21 & 0.39 & 0.47 & 0.610 \\
\hline No support to publicize AIDS & 0.21 & 0.39 & 0.67 & 0.29 & 0.62 & 0.61 & 0.620 \\
\hline Population Vulnerability & 8.55 & 10.58 & 12.86 & 11.31 & 8.48 & 9.91 & 10.12 \\
\hline
\end{tabular}


Am. J. Infect. Dis., 7 (2): 32-39, 2011

Table 2: Parameter estimates of Cobb-douglas production frontier for households with and without infection

\begin{tabular}{|c|c|c|c|c|c|}
\hline \multirow[b]{2}{*}{ Variables } & \multirow[b]{2}{*}{ Parameter } & \multicolumn{2}{|c|}{ Household with infection } & \multicolumn{2}{|c|}{ Households without infection } \\
\hline & & Coefficients & t-ratios & Coefficients & t-ratios \\
\hline Constant & Bo & $4.491 * * *$ & 4.528 & $12.528 * * *$ & 11.842 \\
\hline Ln farm size & $\beta_{1}$ & $0.047 * *$ & 2.114 & $0.113^{* * * *}$ & 9.078 \\
\hline Ln Labour/capita & $\beta_{2}$ & $0.455 * *$ & 2.947 & $0.205 * * *$ & 2.241 \\
\hline Education of house head & $\beta_{3}$ & $0.209 * * *$ & 4.861 & $0.039 * * *$ & 2.852 \\
\hline Ln cost of fertilizer & $\beta_{4}$ & -0.017 & -0.362 & -0.215 & -0.273 \\
\hline Ln cost of seed & $\begin{array}{l}\beta_{5} \\
\sigma^{2}\end{array}$ & $\begin{array}{l}0.027 \\
4.020\end{array}$ & 0.438 & $\begin{array}{l}0.017 \\
4.088\end{array}$ & 0.354 \\
\hline & $\gamma$ & $0.930^{* * *}$ & 4.765 & $0.850^{* * *}$ & 3.309 \\
\hline Log likelihood & & -26.390 & & -48.490 & \\
\hline Likelihood ratio test & & $19.810 * *$ & & $39.310 * *$ & \\
\hline
\end{tabular}

Note: ***, ** and $*$ significant at 10,5 and 1 percent respectively

Table 3: Determinants of Inefficiency

\begin{tabular}{|c|c|c|c|c|c|}
\hline \multirow[b]{2}{*}{ Variables status } & \multirow[b]{2}{*}{ Estimates } & \multicolumn{2}{|c|}{ Household with infection } & \multicolumn{2}{|c|}{ Household without infection } \\
\hline & & Coefficients & t-Ratios & Coefficients & t-Ratios \\
\hline Constant & $\delta_{0}$ & $-3.783^{*}$ & -1.909 & -1.967 & -0.779 \\
\hline Age & $\delta_{1}$ & $0.080^{* *}$ & 2.146 & $0.027 * * *$ & 8.341 \\
\hline Fex & $\delta_{2}$ & $0.075^{* * *} *$ & 4.938 & $0.207 * *$ & 2.182 \\
\hline Edu & $\delta_{3}$ & $-0.305^{* * *}$ & -3.146 & $-0.097 *$ & -1.883 \\
\hline Dis & $\delta_{4}$ & $-0.090^{* *}$ & 2.104 & 0.008 & 0.160 \\
\hline Sic & $\delta_{5}$ & $0.997 *$ & 1.702 & $0.227 *$ & 1.915 \\
\hline Fer & $\delta_{6}$ & -0.057 & -0.099 & -0.044 & -0.779 \\
\hline Cop & $\delta_{7}$ & $0.764 * *$ & 2.383 & $0.927 *$ & 1.915 \\
\hline Acc & $\delta_{8}$ & $-0.539 * *$ & -2.699 & $0.860 *$ & 1.762 \\
\hline Ext & $\delta_{9}$ & 0.536 & 0.908 & $2.187 * *$ & 2.108 \\
\hline Hss & $\delta_{10}$ & 0.015 & 0.844 & 0.243 & 0.421 \\
\hline
\end{tabular}

Note: $* * *, * * *$ and $*$ significant at 10,5 and 1 percent respectively

Table 4: Distribution of economic efficiency of households with and without HIV/AIDS infection

\begin{tabular}{|c|c|c|c|c|}
\hline \multirow[b]{2}{*}{ Efficiency range } & \multicolumn{2}{|c|}{$\begin{array}{l}\text { Households } \\
\text { with infection }\end{array}$} & \multicolumn{2}{|c|}{$\begin{array}{l}\text { Households } \\
\text { without infection }\end{array}$} \\
\hline & Mean & $(\%)$ & Mean & $(\%)$ \\
\hline $0.01-0.20$ & 0.1224 & 12.31 & 0.1249 & 6.67 \\
\hline $0.21-0.40$ & 0.3338 & 7.69 & 0.3319 & 20.00 \\
\hline $0.41-0.60$ & 0.5593 & 35.39 & 0.5515 & 13.33 \\
\hline $0.61-0.80$ & 0.7748 & 23.08 & 0.7634 & 44.44 \\
\hline $0.81-1.00$ & 0.9314 & 13.85 & 0.9058 & 15.57 \\
\hline Grand Mean & 0.4910 & & 0.7310 & \\
\hline
\end{tabular}

HIV/AIDS and productivity variability in farm households: The Cobb-Douglas production frontier estimates the maximum likelihood estimates of the production frontier and determinants of inefficiency.

Determinants of productivity variability: The inefficiency model has shown deviation from the frontier output. These differences can be accounted by the inefficiency factors included in the model and the result is presented in Table 3. It is important to note that the individual level variable in households is taken in reference to the head of the households. It is assumed that most of the household responsibilities and decisions are shouldered by the head of the household.
Economic efficiency of farm households: The Frontier model estimates farm-specific or individual efficiencies. The range distribution of efficiencies of HIV with and without infection is presented Table 4. The efficiency ranges are presented in five classes.

\section{DISCUSSION}

The vulnerability analysis is important to actually identify attributes that pre-dispose individuals to HIV/AIDS infection. Some attributes were identified that can expose individuals to infection are regarded as indices of vulnerability. Individual behavioural responses were used to establish population vulnerability. The population vulnerability shows that $10.12 \%$ of households were vulnerable to HIV/AIDS infection. The percentage vulnerability in the LGAs are $8.85,10.58,12.86,11.31,8.48$ and $9.91 \%$ for Ukwa East, Ukwa West, Umuahia North, Isialangwa North, Ohafia and Arochukwu Local Government Areas respectively.

In Ukwa East, the factors with the highest contributions to vulnerability are: have not heard about AIDS (0.92\%) and cannot get condom $(0.90 \%)$. In Ukwa West, having more than one sex partner contributed the highest $(0.96 \%)$, followed by non use 
condom $(0.94 \%)$. In Umuahia North equally having more than one partner contributed the highest $(0.98 \%)$ followed by patronage prostitutes $(0.91 \%)$. In Isialangwa North, sharing injection needles contributed the highest $(0.91 \%)$ followed by inability to get condom $(0.83 \%)$. In Ohafia, it was, have not heard about AIDS $(0.81 \%)$ and do not know preventive measures $(0.66 \%)$. In Arochukwu, the highest contribution came from care not to touch blood. In general, the factors that contributed the highest to vulnerability indices were, do not care to contract AIDS and non-use of condoms which contributed $0.81 \%$ each.

The coefficients of farm size, labour and education have the expected signs and are significant. Farm size is significant at 5\% in households with infection and at $1 \%$ in households without infection. It is expected that productivity will increase in households as the area of land cultivated increases. Similar results were obtained by Elibariki et al. (2008); Barnes (2008) and Basnayake and Gunaratne (2002) among smallholder maize farmers in Tanzania, Scottish cereal producers and Sri Lanka tea smallholders respectively. However, it is important to note the size of the coefficient for farm size is higher in households without infection. The implication is that returns due to increments in farm size cultivated will result in higher productivity in households without infection than in households with infection. Labour is positive and significant at 5\% underscoring its importance in labour- intensive agriculture. Labour is the single most important factor of production with elasticity's of 0.455 and 0.205 in households with infection and without infection respectively. Elibariki et al. (2008) decomposed labour into hired and family labour and reported a negative and significant coefficient of family labour for smallholder maize farmers in Tanzania. Education has been reported in many studies to have a positive effect on productivity. Our results show the importance of education in increasing productivity as both coefficients are statistically significant at one \% and positive. The non-significance of fertilizer and seeds/seedlings can be attributed to the low level of application of fertilizer occasioned by the scarcity of the product and the heavy dependence on traditional or local seed.

It should be noted that in the inefficiency model (Table 3), variables are included as inefficiency variables; thus a negative coefficient means an increase in efficiency and a positive effect on productivity. In households with infection, age of household head, farming experience and market days lost as a result of sickness were positive and significant at 5, 1 and 10\% respectively. As the household head ages the zeal to undertake innovative changes decreases and as such impacts negatively on efficiency and household productivity. Young people are better risk-takers when compared to older people. Number of market days lost as a result of sickness assumed expected sign and will affect efficiency as a major part of income accruing to households comes from sales of subsistence products in local markets. Education as a priori expected is negative and significant. The better educated head of household is more informed and in a better position to grapple with modern techniques of farming and ability to access modern inputs. This result is in tandem with results obtained by Elibariki et al. (2008). Distance to market is negative and significant at 5\%. Transportation is a major problem in rural areas and as such the closer the market the better for the farm household. Petty trading in household consumables and farm commodities are major economic activities in rural areas.

Similar trend is observed in households with infection were age and farming experience are positive and significant at 1 and 5\% respectively. Again, education is found to be significant at $10 \%$ and negative. Another important observation is that while access to credit impacted positively on productivity in households with infection, it was otherwise in households without infection. Other plausible results of the study are that of cooperative membership and extension visits. While cooperative membership was significant, it impacted negatively on productivity in both households. Extension visits was significant and positive in only households without infection. No plausible reason could be proffered readily for this behavior. But of note is that most Extension Officers operate from outside their primary place of assignment and as such may not be on hand readily to tackle problems of farmers.

The mean efficiency obtained in households with infection is $49.1 \%$ against $73.1 \%$ in households without infection. Households without infection are economically more efficient compared to households with infection. This is a priori expected since households with infection have many factors to grapple with. Much time and resources are spent on taking care of the victim. On average household with infection incurs $50 \%$ loss in productivity as a result of inefficiency in the use of resources. If the inefficiency factors are fully addressed the household has opportunity of increasing productivity by $50 \%$ given existing technologies and resources? It is important to note that in both households there are rooms for productivity increases. Farm households are inefficient in the use of existing resources. 


\section{CONCLUSION}

The impact of HIV/AIDS in Africa cut across all sectors of human development and it poses serious challenge to the survival of several vulnerable poor, whose livelihood depends solely on agriculture. The 2005 sentinel survey put the prevalence rate of HIV/AIDS in rural areas of Abia State at $7.7 \%$ against the urban value of $2.2 \%$. This study investigated productivity variability in households with and without HIV/AIDS infection since agriculture is the major livelihood activity in rural areas. A sample of 110 households comprising of 65 with HIV/AIDS infection and 45 without infection were drawn from Local Government areas in Abia State, Nigeria. Household surveys were carried out to elicit information on socioeconomic demographic and farm activities. The Fussy set approach was adopted in evaluating vulnerability to HIV/AIDS pandemic. The Frontier model that estimates efficiency was used in ascertaining agricultural productivity in farm households. The vulnerability factors showed that $10.12 \%$ of the households were vulnerable to HIV/AIDS. Non-use of condoms and having multiple sex partners were the most pronounced vulnerability indices. The frontier model revealed that farm size, labour and education were positive determinants of productivity variability in farm households. Both households were below the frontier output implying that they were inefficient in the use of resources. However households with infection were more inefficient compared to households without infection. There are rooms for increasing productivity in households if the inefficiency factors are addressed. One policy implication arising from the study is the review of agricultural extension policy to make it more relevant to cope with changing rural dynamics.

\section{REFERENCES}

Ambe-Uva, T.N., 2005. Eclecticism beyond orthodoxies: African social science research in the fight against HIV/AIDS. J. Soc. Sci., 1: 178-183. DOI: $10.3844 /$ jssp.2005.178.183

Barnes, A., 2008. Technical efficiency estimates of scottish agriculture: A note. J. Agric. Econ., 59: 370-376. DOI: 10.1111/j.1477-9552.2008.00156.x

Basnayake, B.M.J.K. and L.H.P. Gunaratne, 2002. Estimation of technical efficiency and it's determinants in the tea small holding sector in the mid country wet zone of Sri Lanka. Sri Lanka J. Agric. Econ., 4: 137-150.

Christiaensen, L.J. and K. Subbarao, 2005. Towards an understanding of household vulnerability in Rural
Kenya. J. Afr. Econ., 14: 550-558. DOI: 10.1093/jae/eji008

Coelli, T., 1996. A Guide to FRONTIER Version 4.1: A Computer Program for Stochastic Frontier Production and Cost Function Estimation. CEPA Working Papers, 96/07, University of New England, Australia.

CTA, 2004. The HIV/AIDS pandemic - a threat for rural communities and agricultural productivity in ACP countries. Technical Centre for Agricultural and Rural Cooperation ACP-EU.

Elibariki, E.M., S. Hisano and T. Nariu, 2008. Explaining Productivity Variation among Smallholder Maize Farmers in Tanzania.

Jamshidi, M.M., D. Parivash, A.H. Madani, A. Azadeh and A. Zinab et al., 2010. Knowledge and attitude of persons living with HIV+/AIDS. Am. J. Infect. Dis., 6: 70-74. DOI: 10.3844/ajidsp.2010.70.74

Joseph, T.M., 2005. Balancing treatment and prevention: The case of HIV/AIDS. Am. J. Applied Sci., $\quad 2$ : $1380-1388 . \quad$ DOI: 10.3844/ajassp.2005.1380.1388

Kermyt, G.A. and A.M. Beutel, 2007. HIV/AIDS prevention knowledge among youth in cape town South Africa. J. Soc. Sci., 3: 143-150. DOI: 10.3844/jssp.2007.143.150

Luers, A.L., D.B. Lobell, L.S. Sklar, C.L. Addams and P.A. Matson, 2003. A method for quantifying vulnerability, applied to the agricultural system of the yaqui valley, Mexico. Global Environ. Change, 13: 255-267. DOI: 10.1016/S0959-3780(03)000542

Masuku, M.B. and M.M. Sithole, 2009. The Impact of HIV/AIDS on food security and household vulnerability in Swaziland. Agrekon, 48: 1-22.

Nirmala, R., J.B. Suchitra, A. Shet, Z.K. Khan and J. Wigdahl et al., 2009. Mortality among HIVinfected patients in resource limited settings: A case controlled analysis of inpatients at a community care center. Am. J. Infect. Dis., 5: 219224. DOI: 10.3844 /ajidsp.2009.219.224

NPC, 2006. National Population Housing and Census Estimate, Nigeria.

Oyekale, A.S., 2004. Rural Household's Vulnerability to HIV/AIDS and Economic Efficiency in the Rainforest Belt of Nigeria.

Pradeep, M.A., M. Thiruvalluvan, K. Aarthy and J.M. Mary, 2010. Determination of iron deficiency among human immunodeficiency virus sero positives. Am. Med. J., 1: 77-79. DOI: 10.3844/amjsp.2009.77.79 
Robert, M.M., R. Rosenberg, G. Donenberg and J.G. Dévieux, 2006. interventions and patterns of risk in adolescent HIV/AIDS prevention. Am. J. Infect. Dis., 2: 80-89. DOI: 10.3844/ajidsp.2006.80.89

Sarder, N., S.J. Uddin, Hossain, M.N. Huda, M.H. Rahman and M.E. Ali, 2006. Consequence on treatment of TB patients affected by HIV/AIDS a conceptual research. Am. J. Infect. Dis., $\quad 2$ 2: 210-218. 10.3844/ajidsp.2006.210.218

Sumathi, M., M. Bala, R.K. Jain, M. Malhotra and K. Ray, 2010. Hepatitis B and C positivity in various categories of human immunodeficiency virus seropositive individuals in a regional STD centre-an eight-year evaluation of trends and risk factors. Am. Med. J., 1: 103-108. DOI: 10.3844/amjsp.2009.103.108
UNAIDS, 2001. Declaration of Commitment on HIV/AIDS "Global Crisis-Global Action".

UNAIDS, 2002. Joint United Nations Programme on HIV/AIDS Epidemic Geneva, Switzerland.

United Nations, 2006. The millennium development goals report 2006. New York. 